\title{
Characterization by Mössbauer spectroscopy of Fe phases in highly weathered serpentinitic soil from southern Cameroon
}

\author{
C. VAN CROMPHAUT ${ }^{1, *}$, E. VAN RANST ${ }^{2}$, V. G. DE RESENDE ${ }^{1}$, \\ R. E. VANDENBERGHE ${ }^{1}$, E. DE GRAVE ${ }^{1}$ AND G. LAMBIV DZEMUA ${ }^{3}$ \\ ${ }^{1}$ Department of Subatomic and Radiation Physics, Ghent University, Proeftuinstraat 86, 9000 Ghent, Belgium, \\ ${ }^{2}$ Department of Geology and Soil Science, Ghent University, Krijgslaan 281 (S8), 9000 Ghent, Belgium, and \\ ${ }^{3}$ Geovic Cameroon PLC, BP 11555, Yaounde, Cameroon
}

(Received 1 April 2007; revised 27 September 2007)

\begin{abstract}
Weathered soil material derived from tectonically emplaced serpentinized ultrabasic intrusive rocks of southern Cameroon has received considerable attention from mining companies due to its extractable-metal (i.e. $\mathrm{Ni}, \mathrm{Co}$ ) potential. As these cations can be incorporated into $\mathrm{Fe}$ oxides, it was deemed appropriate to study the mineralogical assemblage of a highly weathered serpentinite soil profile from the area. This study focuses on the different Fe-oxide phases, which were investigated using ${ }^{57} \mathrm{Fe}$ Mössbauer spectroscopy, showing goethite and hematite as the dominant $\mathrm{Fe}$ oxides throughout the weathering profile. These minerals, in association with gibbsite and kaolinite, indicate an advanced degree of weathering. The clay fraction of the 'Lower Limonite' layer, above the saprolite and at a depth of $7 \mathrm{~m}$, is very rich in goethite, whereas hematite and magnetite are almost absent. Above this layer, the hematite content in the fine-earth and clay fractions increases upwards, while the goethite content remains constant. The significant substitution and change in the particle size of the goethite and the poor crystallinity of hematite, as indicated by the hyperfine parameters and XRD, suggest that the upper material evolved under different pedological conditions compared to the deeper layers. The mixed composition of the upper layers (above $7 \mathrm{~m}$ ), which contain muscovite and a relatively chaotic distribution of trace elements, suggests ancient mica-schist capping and possibly different cycles of erosion and pedimentation.
\end{abstract}

KEYwords: serpentinitic soil, Cameroon, Mössbauer spectroscopy, X-ray diffraction.

From the humid southern plateau to the arid northern lowlands bordering Lake Chad, Cameroon's landscape harbours examples of virtually all the environments of tropical Africa and has a large variety of soils derived from

* E-mail: caroline.vancromphaut@ugent.be DOI: $10.1180 /$ claymin.2008.043.1.09 different parent rocks and materials. In the humid southern part of the country, long and intense weathering of the Precambrian rocks has resulted in thick lateritic soils (Yerima \& Van Ranst, 2005). The Precambrian rocks of Cameroon have classically been divided into two major groups: the Archaean cratonic basement underlying the southern area of the country and the Neoproterozoic mobile belt underlying the central and northern parts. The Archaean rocks are interpreted to be a northern extension of the 
Congo craton, well known for its mineral wealth. Deformation and metamorphism of these rocks during the early and late Proterozoic have been the basis for mineral exploitation in this region for decades (Bessoles, 1980).

Within an intermediate tectonic setting between the Congo craton and the mobile (orogenic) belt, a series of tectonically emplaced, serpentinized, ultrabasic intrusive complexes crop out locally, probably as a result of combined erosion and tectonic uplift. Over the last three decades this serpentinite has received considerable attention because of its mineral potential (Yongue-Fouateu et al., 2006; Milesi et al., 2006). The serpentinite soil was briefly evaluated during the early 1980 s as part of the 'inventory of the mineral resources of Cameroon', sponsored by the United Nations Development Program (UNDP). The inventory indicated the presence of an extensive vertical and lateral section of moderate-grade nickel mineralization, hosted in the weathered material and overlying the serpentinite parent-rock.

Subsequently, some mining companies examined the area and concluded, based on contemporary technological information, that the mineral content was sub-economic. Recently, one company observed an anomalously high cobalt grade in some samples of the weathered material. The exploitation potential of this resource is relatively small due to the large spatial variation in grade between and within profiles. So far very few mineralogical investigations of the entire weathering profile have been undertaken. Therefore, a more detailed mineralogical examination of a selected profile has been performed with an emphasis on the different Fe-oxide phases, studied using Mössbauer spectroscopy. Iron oxides will play an important role in the behaviour of elements such as $\mathrm{Ni}$, Co and $\mathrm{Cr}$, as these elements are often present in natural Fe oxides (Trolard et al., 1995; Schwertmann \& Pfab, 1996).

Strongly weathered lateritic soils are usually situated on geomorphologically flat to undulating old surfaces, which have formed through erosional and depositional processes (Van Wambeke et al., 1980). Many such soils, although clearly transported and reworked, show a clear relationship with the currently underlying or proximal saprolites. Highlyweathered lateritic soils may be regarded as mineralogical assemblages and secondary minerals of great stability, in which a few major constituents often make up as much as $90 \%$ of the total. Among these minerals are the 1:1 layer silicates of the kaolinite group, oxides of $\mathrm{Fe}, \mathrm{Al}$ and $\mathrm{Ti}$ and some highly resistant minerals either inherited or transformed from the parent rock, such as quartz, muscovite and sometimes Al hydroxy-interlayered vermiculite (Herbillon, 1980; Qafoku et al., 2004). Numerous studies have reported the common occurrence of muscovite in such soils derived from micaceous parent rocks, suggesting it is extremely resistant to weathering under base-depleted conditions, such as those prevailing in the humid tropics (Herbillon, 1980). The Fe (oxyhydr)oxide minerals present in these soils are largely responsible for the deep red, reddish brown and orange to yellowish colours (Cornell \& Schwertmann, 2003). The differentiation of the various species of $\mathrm{Fe}$ (oxyhydr)oxide minerals by conventional techniques is difficult because of the considerable overlap in their physical characteristics and X-ray diffraction (XRD) patterns. Furthermore, Fe oxides in highly weathered soils (HWS) are often poorly crystallized, resulting in broad diffraction peaks which are difficult to detect and resolve in an XRD pattern (Van Ranst \& Eswaran, 1998). The ${ }^{57} \mathrm{Fe}$ Mössbauer spectroscopy technique offers several advantages for studies of Fe-containing compounds (Murad, 1998). It is specific for $\mathrm{Fe}$ and the results (i.e. the various Mössbauer parameters) are extremely sensitive to the electronic, magnetic and structural features of the Fe-bearing phases involved. This generally allows phase identification and quantitative phase analysis of $\mathrm{Fe}$ oxides that are present in relatively small concentrations in soil aggregates, and as such difficult to resolve in XRD patterns.

Among the Fe oxides, goethite and hematite are the most abundant minerals in HWS. The formation of these $\mathrm{Fe}$ oxides during weathering is governed by the presence of fine-grained minerals, mainly clay silicates. These minerals have an influence on the ratio of goethite to hematite, their crystallinity and their crystal chemistry, such as Al-for-Fe substitution (Baert et al., 1999; Schwertmann et al., 2000). The concentration of kaolinite, in particular, is associated with the Al substitution in hematite and goethite over different areas of the profile of highly developed soils from Cameroon (Muller \& Bocquier, 1985). The variation in Al-forFe substitution may be used to characterize the present and former $\mathrm{Al}$ availability relative to $\mathrm{Fe}$ availability in the pedo-environment, which is mainly determined by $\mathrm{pH}$ and the degree of desilicification (Van Ranst, 1995). 


\section{MATERIALS AND METHODS}

\section{Environmental setting}

The selected serpentinitic soil profile is located in Lomie, in the Nkamouna ultrabasic massif of the southern continental agro-ecological zone. Around the serpentinized ultrabasic complex, the bedrock is mainly composed of early Proterozoic metasedimentary schists. The area is characterized by a semi-deciduous forest with a Guinea-type equatorial climate, having four seasons in a year (two rainy and two dry) and abundant rains $(1600 \mathrm{~mm})$. This type of climate is characterized by high and fairly constant temperatures, averaging $25^{\circ} \mathrm{C}$, with a constantly high relative humidity $(>80 \%)$. The profile is located on a plateau, $753 \mathrm{~m}$ above sea level, which is typical for the region and has many deep and broad incisions as a result of the uppermost reaches of the Congo River drainage system. It is mainly characterized by deeply weathered areas or HWS which are red or yellow in colour and strongly leached. The selected profile contains five units: (1) the 'Upper Limonite'; (2) the 'Upper Breccia', a 'hardpan' and the 'Lower Breccia'; (3) the clayey 'Lower Limonite'; (4) the saprolite; and (5) the serpentinite rock. The sequence 'Lower Limonite' to 'Upper Limonite' has been studied using Mössbauer spectroscopy.

\section{Soil samples}

Bulk samples were collected across each unit, homogenized and reduced in volume using a Rifle Jones sample splitter. The samples were air-dried, lightly pulverized and sorted using a $2 \mathrm{~mm}$ sieve (dry method). All the samples were analysed for routine physicochemical properties and by XRD. The fine-earth $(<2 \mathrm{~mm})$ fraction of four samples was retained for Mössbauer spectroscopy.
Codenames, depth, lab numbers and the dry Munsell soil colours are given in Table 1 .

From the fine-earth fraction, the sand fraction was separated by sieving and the clay portion removed from the silt using a successive sedimentation method. For the clay separation, $\mathrm{Na}_{2} \mathrm{CO}_{3}$ and $\mathrm{NaCl}$ were used as dispersion and flocculation agents, respectively. After two months, the separated clay was washed thoroughly with alcohol to remove the $\mathrm{Cl}^{-}$from the flocculating agent. During washing, each sample was centrifuged at $\sim 3500 \mathrm{rpm}$ and finally $\mathrm{AgNO}_{3}$ was used to confirm that each sample was free of $\mathrm{Cl}^{-}$. The clay fractions of the aforementioned samples are marked with an index ' $c$ ' in the corresponding sample number.

\section{Analyses}

The total elemental composition of each sample was determined after: (1) fusion with $\mathrm{Li}_{2} \mathrm{CO}_{3}$ and $\mathrm{H}_{3} \mathrm{BO}_{3}$ at $1000^{\circ} \mathrm{C}$ and dissolution in $\mathrm{HCl}$ for determination of $\mathrm{Si}$ and $\mathrm{Al}$ with atomic absorption spectrophotometry (AAS) in a $\mathrm{N}_{2} \mathrm{O}$ flame; and (2) a treatment with $\mathrm{HF}+\mathrm{HNO}_{3}+\mathrm{HClO}_{4}$ and dissolution of the evaporation residue in $\mathrm{HCl}$ for determination of $\mathrm{Fe}, \mathrm{Ca}, \mathrm{Mg}, \mathrm{K}, \mathrm{Na}$ and $\mathrm{Mn}$ with AAS in an air-acetylene flame and $\mathrm{Ti}$ and $\mathrm{P}$ colorimetrically (Ingamells, 1966; Omang, 1969). Loss on ignition (LOI) was determined at $1000^{\circ} \mathrm{C}$. The four selected fine-earth and corresponding clay samples were also treated with acid-ammonium oxalate (Schwertmann, 1964) and dithionite-citratebicarbonate (DCB) following the method of Mehra \& Jackson (1960) and the Fe content in the respective extracts was determined by AAS. Some metal $(\mathrm{Ni}, \mathrm{Co}$ and $\mathrm{Cr}$ ) contents in the fine-earth were determined by inductively coupled plasma mass spectrometry (ICP-MS).

TABLE 1. Stratigraphic positions of the selected samples, laboratory numbers for the fine-earth and clay samples, and the Munsell colour of the complete samples.

\begin{tabular}{llccl}
\hline $\begin{array}{l}\text { Depth } \\
(\mathrm{m})\end{array}$ & \multicolumn{1}{c}{ Unit code } & $\begin{array}{c}\text { Sample } \\
\text { (Fine-earth fraction) }\end{array}$ & $\begin{array}{c}\text { Sample } \\
\text { (Clay fraction) }\end{array}$ & Munsell colour (dry) \\
\hline $1-2$ & $\begin{array}{l}\text { Upper Limonite/Upper } \\
\text { Breccia }\end{array}$ & 1901 & $1901 \mathrm{c}$ & 2.5YR 4/8, red \\
$5-6$ & Hardpan/Lower Breccia & 1903 & $1903 \mathrm{c}$ & 2.5YR 5/8, red \\
$6-7$ & Lower Breccia & 1904 & $1904 \mathrm{c}$ & 7.5 YR 6/8, reddish yellow \\
$10-11$ & Lower Limonite & 1906 & $1906 \mathrm{c}$ & 10YR 6/8, brownish yellow
\end{tabular}


X-ray diffraction patterns were collected using a Philips X'PERT SYSTEM with a PW 3710 based diffractometer, equipped with a $\mathrm{Cu}$ tube, a secondary graphite beam monochromator, a proportional xenon-filled detector and a 35 position multiple-sample changer. The tube was operated at $40 \mathrm{kV}$ and $30 \mathrm{~mA}$ and the XRD data collected in a $2 \theta$ geometry from $3.00^{\circ}$ onwards, at a step of $0.020^{\circ} 2 \theta$ and a count time of $1 \mathrm{~s}$ per step. Phase identification was carried out using the software $\mathrm{Jade}^{+}$.

Mössbauer spectra were collected at room temperature (RT) and $80 \mathrm{~K}$ for the four fine-earth fraction samples and the respective clay fractions. A spectrometer operating in constant acceleration mode with triangular reference signal and a ${ }^{57} \mathrm{Co}(\mathrm{Rh})$ source were used. For each sample, $60 \mathrm{mg}$ of material was used in the Mössbauer mounts $\left(1.25 \mathrm{~cm}^{2}\right)$. The samples contain a reasonable amount of $\mathrm{Fe}$ (16-42 wt.\%; see next section) divided among different Fe-bearing phases and therefore thickness effects, as reflected in lineshape distortions for the distinct spectral components, are expected to be insignificant. Accumulation of the data was performed in 1024 channels using the WISSEL CMCA-550 unit and continued until the background count reached $10^{6}$. The spectrometer was calibrated by collecting the spectrum of a standard $\alpha-\mathrm{Fe}_{2} \mathrm{O}_{3}$ powder at RT; hence, isomer shift values quoted hereafter are with respect to $\alpha-\mathrm{Fe}$ at RT. Sample 1906 was measured at $140 \mathrm{~K}$ instead of $80 \mathrm{~K}$ due to the presence of a small amount of magnetite in this sample. Magnetite at temperatures below $\sim 130 \mathrm{~K}$ produces a complicated and poorly understood multiplesextet spectrum (Vandenberghe \& De Grave, 1989) that cannot adequately be resolved when a mixture with other $\mathrm{Fe}$ oxides is involved. The Mössbauer spectra were computer analysed in terms of model-independent distributions of hyperfine- parameter values and the numerical data quoted hereafter refer to maximum-probability values. For sextet subspectra, peak-area ratios were constrained to $3: 2: 1: 1: 2: 3$ and for doublets $1: 1$. Each elemental sextet and doublet of the respective distributions was adjusted with one line-width parameter. For the RT spectra, this line-width had to be fixed for the smeared-out goethite sextet and a value of $0.25 \mathrm{~mm} / \mathrm{s}$, which is the approximate instrumental width, was chosen.

\section{RESULTS AND DISCUSSION}

X-ray diffraction analysis revealed that all selected samples contain kaolinite and goethite $(\alpha-\mathrm{FeOOH})$; gibbsite $\left(\mathrm{Al}[\mathrm{OH}]_{3}\right)$, muscovite and hematite $\left(\alpha-\mathrm{Fe}_{2} \mathrm{O}_{3}\right)$ were observed in some of the samples. Muscovite and hematite seemed to be absent from the 'Lower Limonite' layer and gibbsite from the 'Lower Breccia' layer. The major parent rock (serpentinite) minerals, serpentine and magnesite (Lambiv Dzemua, 2005), have not been detected in the weathered material above the saprolite. In the saprolite, trioctahedral serpentine has been replaced by kaolinite, its dioctahedral counterpart, while magnesite has been dissolved. This suggests strong weathering and leaching of mainly $\mathrm{Mg}$ and an input of Al. A typical XRD pattern is reproduced in Fig. 1 and refers to the fine-earth fraction of sample 1903. The (qualitative) mineralogical composition of the weathering profile as determined by XRD is summarized in Table 2. Although kaolinite is a common clay mineral often identified in highly weathered tropical soils (Eswaran et al., 1977; Van Ranst et al., 1998), the presence of gibbsite in the 'Lower Limonite' layer suggests some congruent dissolution of kaolinite. Such an autochthonous indirect genesis of gibbsite (or authigenic gibbsite) has been reported previously (Sieffermann \& Millot, 1969). A notable amount of gibbsite was

TABLE 2. Mineralogical composition of the selected samples based on XRD analysis.

\begin{tabular}{|c|c|c|c|c|c|c|}
\hline Sample & Depth (m) & Kaolinite & Gibbsite & Mica & Goethite & Hematite \\
\hline 1901 & $1.2-3$ & $X(m)$ & X (s) & $X(w)$ & $X(\mathrm{~m})$ & X (s) \\
\hline 1903 & $6-9$ & X (s) & $X(\mathrm{~m})$ & $X(s)$ & $X(w)$ & X (w) \\
\hline 1904 & $9-10$ & $X(s)$ & - & X (m) & $X(\mathrm{~m})$ & - \\
\hline 1906 & $11-12$ & $X(s)$ & $X(w)$ & - & $X(\mathrm{~m})$ & - \\
\hline
\end{tabular}

$\mathrm{X}$ : identified

$\mathrm{s}$ : strong; m: medium; w: weak 


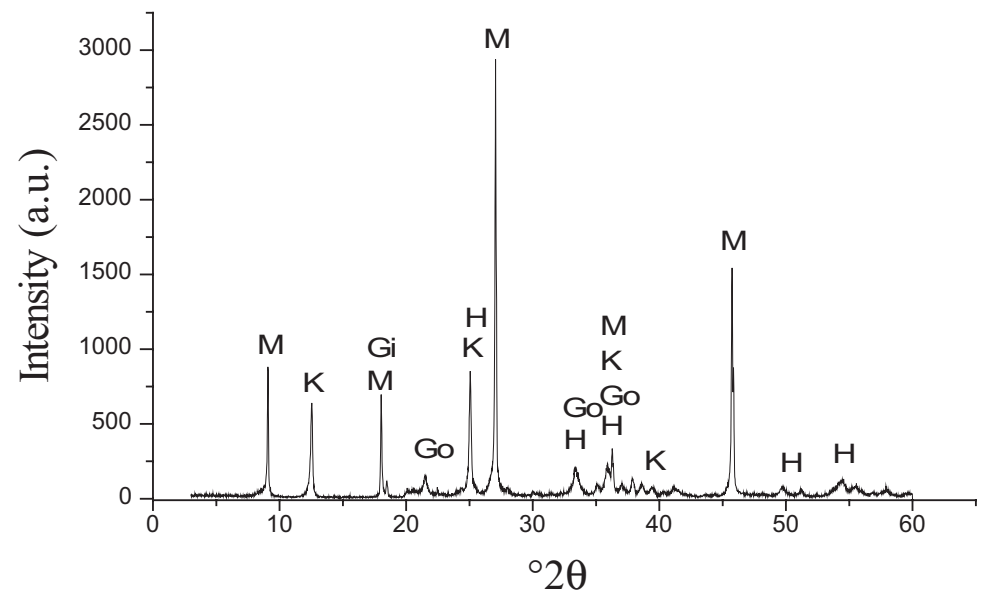

FIG. 1. XRD pattern obtained from the fine-earth fraction of sample 1903. Principal Bragg peaks of kaolinite (K), muscovite $(\mathrm{M})$, hematite $(\mathrm{H})$, gibbsite $(\mathrm{Gi})$ and goethite $(\mathrm{Go})$ are indicated.

determined in the hardpan. Due to the significant overlap of the XRD patterns of muscovite and kaolinite with those of goethite and hematite, it was difficult to assess from XRD the presence of the Fe oxide phases in all of the samples involved.
The Mössbauer spectra at RT and $80 \mathrm{~K}$ of samples 1901, 1903 (Figs 2a and b, respectively) and 1904 are similar and consist of three components, i.e. a well-resolved hematite sextet, a ferric doublet and a very broad sextet, attributed

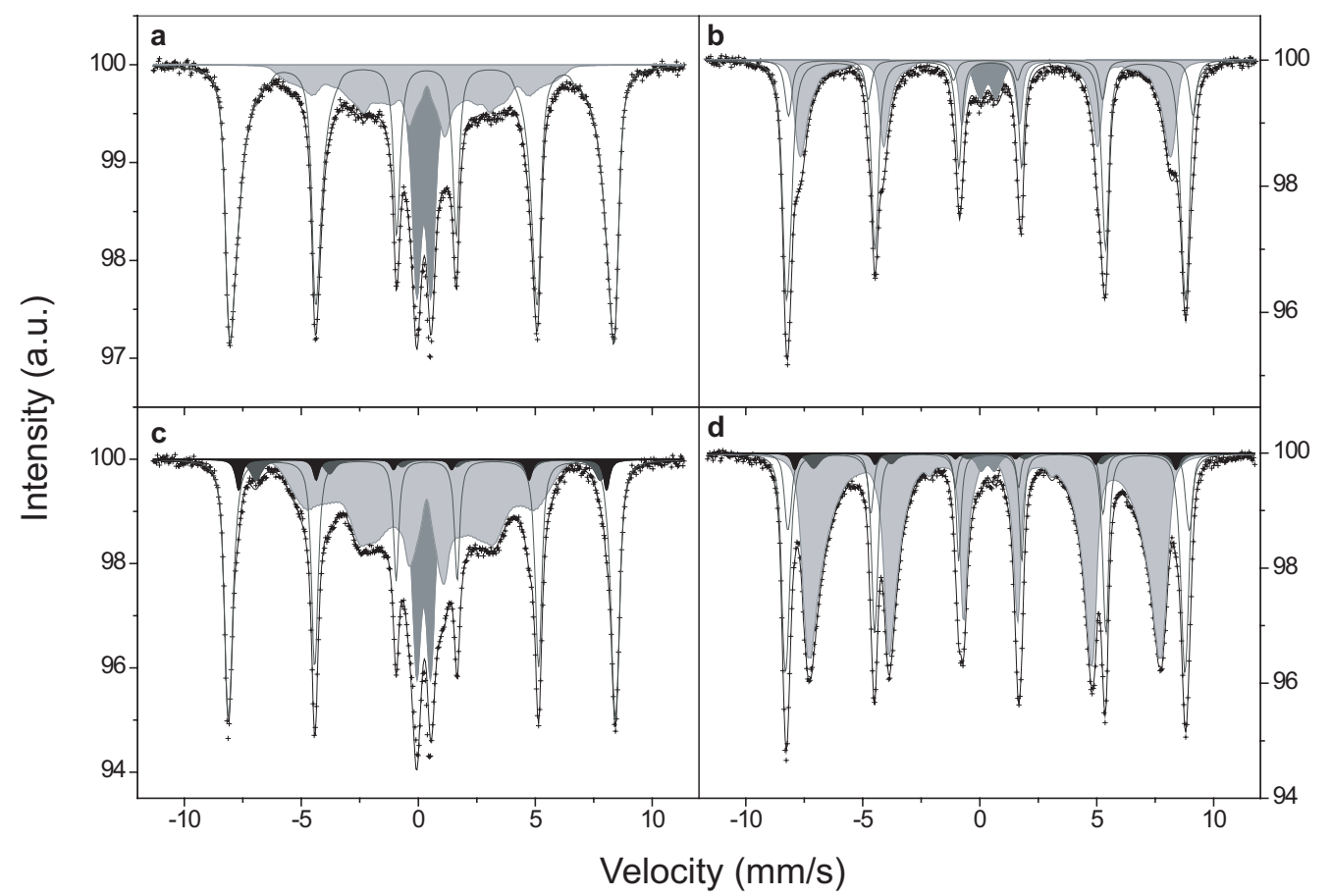

FIG. 2. Mössbauer spectra of samples 1903 and 1906 at: (a) room temperature (1903); (b) $80 \mathrm{~K}$ (1903); (c) room temperature (1906); and (d) $140 \mathrm{~K}$ (1906). Pale-grey shading refers to the goethite component, grey to the ferric doublet and dark-grey to the magnetite sextets. 
here to goethite. In the $80 \mathrm{~K}$ spectra, the doublet has become significantly weaker and the magnetically split component due to goethite is better resolved and exhibits a larger hyperfine field splitting. It is well known that the spectra of goethite, in particular at RT, often consist of a superposition of a doublet arising from superparamagnetic particles and a broadened sextet due to larger particles that remain magnetically ordered at relatively high temperatures (Vandenberghe et al., 2000). This feature explains the spectra in Fig. 2a,b and suggests that the ferric doublets resolved from the RT spectra are due to superparamagnetic goethite. In the numerical analyses of these spectra, the isomer shifts of the ferric doublet and of the goethite sextet were forced to be equal. The subspectrum of hematite at $80 \mathrm{~K}$ is clearly asymmetric in peak depths of the outer absorption lines. This feature occurs because the subspectrum itself is further composed of two distinct components, one attributable to the antiferromagnetic (AF) spin state, the other to the weakly ferromagnetic (WF) state. This coexistence of two spin states is characteristic for soil hematites and is the result of the small particle size and/or Al-for-Fe substitution (De Grave et al., 1983). In fitting the $80 \mathrm{~K}$ hematite components, the isomer shifts and widths of the AF and WF subspectra were constrained to have equal values.

The spectra accumulated at RT and $80 \mathrm{~K}$ for samples 1901c, 1903c and 1904c, representing the clay fractions, closely resemble those of the corresponding fine-earth samples and were therefore adjusted in the same way.

The RT spectrum of sample 1906 (Fig. 2c) essentially consists of the same components as those present in the spectra of the other samples. However, numerous attempts to analyse this spectrum have strongly suggested that an additional weak subspectrum is required to obtain an adequate fit, indicating the presence of a small amount of magnetite $(\sim 7 \%$ of the total $\mathrm{Fe})$ which could not be detected in the XRD patterns because of its small abundance and the proximity of its major reflections to those of other mineral phases present in the soil. Therefore, the RT and $140 \mathrm{~K}$ (Fig. 2d) spectra were adjusted with two additional sextets, corresponding to the tetrahedral $\mathrm{Fe}^{3+}$ and octahedral $\mathrm{Fe}^{2.5+}$ sites of magnetite, respectively. The clay fraction of this sample, 1906c, also contains hematite, goethite and magnetite. However, the relative amount of magnetite is significantly less.
The relevant Mössbauer parameters for the hematite and goethite phases obtained from the numerical data analyses are listed in Table 3. Their values are in line with data reported for other soils containing the two Fe oxides (Vandenberghe et al., 1986, 1990). The non-zero intensity of the doublet in the spectra at $80 \mathrm{~K}$ may indicate the presence of extremely small superparamagnetic goethite particles, or it could reflect the presence of another ferric compound characterized at RT by a doublet which cannot be distinguished from that of goethite. However, its relative intensity $(\sim 3 \%$ of $\mathrm{Fe})$ at $80 \mathrm{~K}$ is very small and consequently, some of its parameters, in particular the isomer shift and the line width, had to be fixed in the iteration procedure (at 0.47 and $0.42 \mathrm{~mm} / \mathrm{s}$, respectively).

The hyperfine field of the WF hematite sextet at RT is smaller than reported for well crystallized hematite $(51.7 \mathrm{~T})$. The relative spectral areas of the $\mathrm{AF}$ and $\mathrm{WF}$ fractions in the MS at $80 \mathrm{~K}$ indicate that the Morin transition takes place at temperatures much lower than those of well crystallized hematite species ( $260 \mathrm{~K}$; Vandenberghe et al., 2001). Both effects are probably a consequence of a significant isomorphous substitution and/or a very small crystallite size (Murad \& Schwertmann, 1986). No significant changes were observed for the hyperfine field of hematite in the different layers. The reduction of the quadrupole shift of the AF phase, from sample 1901 to 1906 , indicates a rotation of the AF spins which is often observed at the beginning of the Morin transition when the AF contribution is small. This is an indication that the Morin transition takes place at lower temperatures with increasing depth, which may be the result of greater Al-for-Fe substitution and/or a smaller crystallite size. The particle size could not be determined from the XRD pattern due to overlapping spectra from other minerals. From careful inspection of the Mössbauer spectra (in particular those at RT) it is also obvious that the sextet of the WF phase of hematite has an asymmetric line shape indicating that the oxide exhibits a range of hyperfine field values. Again, this feature may be related to poor crystallinity and/ or to Al-for-Fe substitution in the hematite lattice (De Grave et al., 1988).

The hyperfine field of the goethite phase is much smaller compared to that of well crystallized goethite $(\sim 380$ kOe at RT (De Grave \& Vandenberghe, 1986)). The hyperfine field distribution (HFD) profiles for goethite contributions to the 80 K Mössbauer spectra of samples 1901, 1903 and 


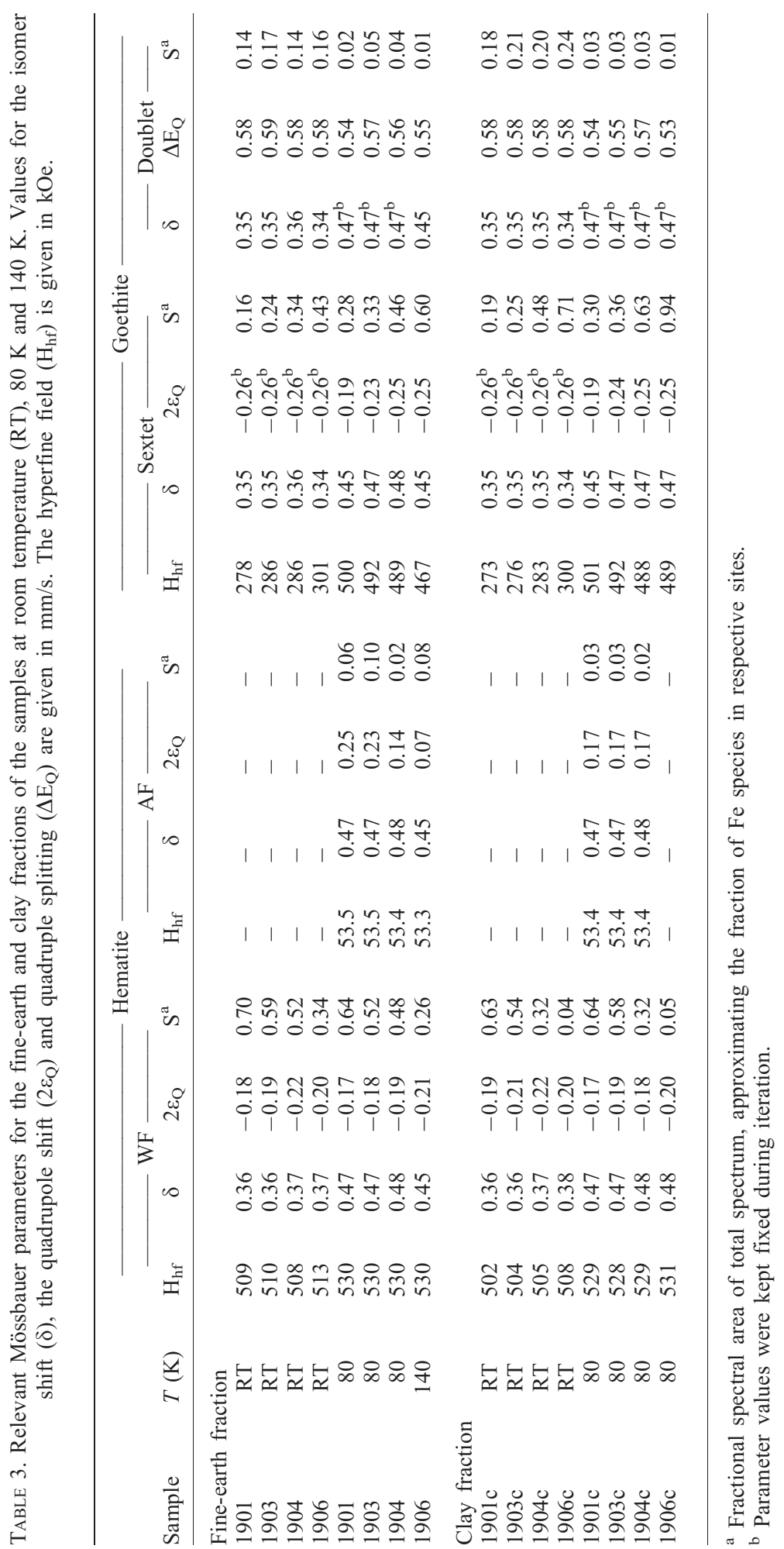




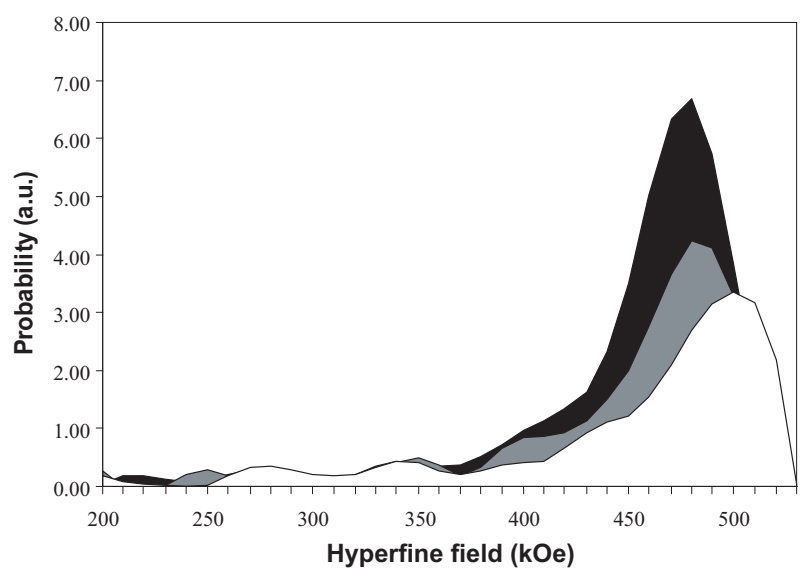

FIG. 3. Hyperfine field distributions of goethite for the $80 \mathrm{~K}$ Mössbauer spectra of samples 1901 (white), 1903 (grey) and 1904 (black).

1904 are shown in Fig. 3. With increasing depth along the soil profile, the hyperfine fields shift to smaller values. The total elemental composition (Table 5) shows that the layers 1901, 1903 and 1904 have approximately the same total $\mathrm{Al}$ content $\left(\sim 25 \% \quad \mathrm{Al}_{2} \mathrm{O}_{3}\right)$, but significantly greater $\mathrm{Si}$ with increasing depth (from $23 \%$ to $35 \% \mathrm{SiO}_{2}$ between 1901 and 1904). Generally, the particle size of goethite is expected to decrease as the $\mathrm{Si}$ content (in the environment where the goethite formed) increases (Quin et al., 1988). To confirm the validity of this correlation for the studied goethite phases, an additional higher-definition XRD measurement was performed. The line width of the well resolved [101] Bragg reflection of goethite, at a $d$ value of $4.15 \AA$, decreased over $0.21,0.18$ and $0.16^{\circ} 2 \theta$ for the Upper Breccia, hardpan and Lower Breccia, respectively, indicating an increasing particle size with depth along the soil profile. This occurs concomitantly with increasing Si availability (see Table 5) and appears to contradict statements in the literature as well as the presently understood behaviour of the goethite hyperfine fields. Another possible explanation for the reduction of the hyperfine field is an increasing Al-for-Fe substitution with increasing depth. The goethite in sample 1901, which has a large hyperfine field, probably has virtually no Al substitution. In samples 1903 and 1904, a considerable amount of $\mathrm{Al}$ must have been substituted to obtain the small hyperfine field.

The hyperfine field of the goethite phase in the clay fraction of 1906 (at $80 \mathrm{~K}$ ) has a value which is comparable to goethites occurring in the upper layers, in spite of snaller total $\mathrm{Al}\left(\sim 12 \% \mathrm{Al}_{2} \mathrm{O}_{3}\right)$ and $\mathrm{Si}$ contents $\left(\sim 12 \% \quad \mathrm{SiO}_{2}\right)$; two factors typically associated with reduced hyperfine fields. The particle size, as suggested by XRD line broadening $\left(0.20^{\circ} 2 \theta\right)$, is smaller than that of the hardpan and Upper Breccia, although the $\mathrm{Si}$ content has decreased. This suggests that an even larger Alfor-Fe substitution has occurred in the Lower Limonite layer. Larger amounts of $\mathrm{Mn}(\sim 2.9 \%$ $\mathrm{MnO}_{2}$ ) and cations, such as $\mathrm{Co}, \mathrm{Cr}$, Ni etc., have been detected, but the effect on the hyperfine field of goethite is much weaker than for Al-substitution and therefore this cannot account for the small hyperfine field.

The hyperfine parameters of the two magnetite sextets resolved from the spectra of samples 1906 and 1906c are listed in Table 4. Slight deviations from values reported in the literature for pure magnetite (De Grave et al., 1993) are apparent and are believed to be due to the weak intensities of both sextets, causing their parameters to be poorly defined. Nevertheless, it is beyond any doubt that both the aforementioned samples do contain magnetite. This magnetite is probably a remnant of that present in the parent rock and hence, of primary origin. The amount of goethite found for the 1906 samples is much greater when compared to other samples, especially in the clay fraction. As goethite forms only in the presence of water, this could be an indication of an increased influence of groundwater at the level of the Lower Limonite unit.

The Fe contents in the clay and fine-earth fractions of the various samples are listed in 
TABLE 4. Mössbauer parameters of the magnetite phase occurring in samples 1906 and 1906c. Values for the isomer shift $(\delta)$ and the quadrupole shift $\left(2 \varepsilon_{\mathrm{Q}}\right)$ are given in $\mathrm{mm} / \mathrm{s}$. The hyperfine field $\left(\mathrm{H}_{\mathrm{hf}}\right)$ is given in kOe.

\begin{tabular}{|c|c|c|c|c|c|c|c|c|c|}
\hline Sample & $T(\mathrm{~K})$ & $\mathrm{H}_{\mathrm{hf}}$ & $\begin{array}{c}\text { Tetra } \\
\delta\end{array}$ & $\begin{array}{l}\mathrm{Fe}^{3+} \\
2 \varepsilon_{\mathrm{Q}}\end{array}$ & $\mathrm{S}^{\mathrm{a}}$ & $\mathrm{H}_{\mathrm{hf}}$ & $\begin{array}{c}\text { Octal } \\
\delta\end{array}$ & $\begin{array}{c}\mathrm{Fe}^{2.5+} \\
2 \varepsilon_{\mathrm{Q}}\end{array}$ & $\mathrm{S}^{\mathrm{a}}$ \\
\hline \multicolumn{10}{|c|}{ Fine-earth fraction } \\
\hline 1906 & RT & 487 & 0.30 & $0^{\mathrm{b}}$ & 0.03 & 455 & 0.56 & $0^{\mathrm{b}}$ & 0.04 \\
\hline 1906 & 140 & 505 & 0.35 & $0^{\mathrm{b}}$ & 0.02 & 484 & 0.79 & $0^{\mathrm{b}}$ & 0.03 \\
\hline \multicolumn{10}{|c|}{ Clay fraction } \\
\hline $1906 \mathrm{c}$ & RT & 487 & 0.34 & $0^{\mathrm{b}}$ & 0.01 & - & - & - & - \\
\hline $1906 \mathrm{c}$ & 80 & - & - & - & - & - & - & - & - \\
\hline
\end{tabular}

${ }^{\text {a }}$ Fractional spectral area of total spectrum, approximating the fraction of $\mathrm{Fe}$ species in respective sites

${ }^{\mathrm{b}}$ Parameter values were kept fixed during iteration

Table 7. After oxalate treatment of the latter fractions, which removes all the poorly crystallized oxides, the Fe contents of the removed fraction were found to be extremely small $(<0.2 \%)$. These results indicate that the amount of $\mathrm{Fe}$ phases in the untreated samples is a good approximation for the content of the different $\mathrm{Fe}$ phases detected by Mössbauer spectra. The relative areas of the spectral components obtained from the analyses of the spectra approximate the distribution of the $\mathrm{Fe}$ among the various $\mathrm{Fe}$ oxides present in the analysed samples (Table 7). Although hematite was not observed in the XRD patterns for samples 1904 and 1906, it is clear from a combination of chemical analyses and spectra that both samples contain a significant amount of hematite $(12 \%$ and $21 \%$ of $\mathrm{Fe}$, respectively). If this hematite is poorly crystallized, its diffraction peaks are broad and difficult to

TABLE 5. Total element composition of the selected fine-earth samples expressed as wt.\% oxides.

\begin{tabular}{lrrrr}
\hline & 1901 & 1903 & 1904 & 1906 \\
\hline $\mathrm{SiO}_{2}$ & 22.88 & 31.77 & 35.46 & 12.13 \\
$\mathrm{Al}_{2} \mathrm{O}_{3}$ & 25.79 & 24.64 & 25.68 & 12.18 \\
$\mathrm{Fe}_{2} \mathrm{O}_{3}$ & 34.31 & 27.18 & 22.46 & 60.62 \\
$\mathrm{TiO}_{2}$ & 2.10 & 2.19 & 3.36 & 0.12 \\
$\mathrm{MnO}$ & 0.17 & 0.14 & 0.46 & 2.86 \\
$\mathrm{CaO}$ & 0.03 & 0.09 & 0.04 & 0.05 \\
$\mathrm{MgO}$ & 0.20 & 0.45 & 0.08 & 0.12 \\
$\mathrm{Na} 2 \mathrm{O}$ & 0.11 & 0.17 & 0.12 & 0.10 \\
$\mathrm{~K}_{2} \mathrm{O}$ & 0.21 & 1.70 & 0.15 & 0.05 \\
$\mathrm{P}_{2} \mathrm{O}_{5}$ & 0.15 & 0.10 & 0.10 & 0.25 \\
$\mathrm{H}_{2} \mathrm{O}$ & 12.96 & 10.83 & 11.56 & 9.61 \\
Total & 98.91 & 99.26 & 99.47 & 98.09 \\
& & & & \\
\hline
\end{tabular}

recognize in a diffraction pattern, even if the hematite is present in relatively large concentrations.

Table 7 shows that the Fe content decreases with increasing depth (samples 1901, 1903 and 1904, respectively) and the colour congruently changes from red (2.5 YR) to reddish-yellow (7.5 YR). This is consistent with the Mössbauer data, i.e. the hematite content of the fine-earth fraction decreases with increasing depth and the goethite content remains approximately constant. The same relationship was found to exist among the clay fractions of the samples. Muller \& Bocquier (1985) reported different conclusions in their investigation of the relationship between large ferruginous nodules (inherited rock texture) and the surrounding clayey matrices (no remaining original rock texture) at different levels in the nodular horizon. They found a progressive decrease in the overall content of $\mathrm{Fe}$ oxides, a decrease in the content of hematite (containing a minor amount of $\mathrm{Al}-$ for-Fe substitution) and an increase in the content of Alsubstituted goethite, from the nodules to the clayey matrix. Assuming that in a weathering profile the deeper the layers, the more the material

TABLE 6. DCB-extracted $\mathrm{Fe}\left(\mathrm{Fe}_{\mathrm{d}}\right.$ in wt.\%) and total contents of $\mathrm{Ni}, \mathrm{Co}$ and $\mathrm{Cr}$ (ppm) determined in the fine-earth fractions of the selected samples.

\begin{tabular}{lcrrr}
\hline Sample no. & $\mathrm{Fe}_{\mathrm{d}}$ & \multicolumn{1}{c}{$\mathrm{Ni}$} & $\mathrm{Co}$ & \multicolumn{1}{c}{$\mathrm{Cr}$} \\
\hline 1901 & 22.90 & 3200 & 70 & 6000 \\
1903 & 18.10 & 1067 & 32 & 3072 \\
1904 & 11.10 & 463 & 23 & 705 \\
1906 & 28.7 & 6827 & 589 & 8845 \\
\hline
\end{tabular}


TABLE 7. The Fe content of the fine-earth and clay fractions of the selected samples (expressed in wt.\%) as determined from total element analysis, as well as the wt.\% of the total mass of soil occurring as hematite, goethite and magnetite as determined by a combination of Mössbauer spectroscopy and chemical analysis of the fine-earth and clay fractions of the samples.

\begin{tabular}{lrcccc}
\hline & Depth & Fe & \% Hematite & \% Goethite & $\%$ Magnetite \\
\hline Fine-earth fraction & & & & & \\
1901 & 1.5 & 24 & 24 & 12 & 0 \\
1903 & 5.5 & 19 & 16 & 13 & 0 \\
1904 & 6.5 & 16 & 12 & 12 & 0 \\
1906 & 10.5 & 42 & 21 & 40 & \\
Clay fraction & & & & & \\
1901 & 1.5 & 35 & 31 & 21 & 0 \\
1903 & 5.5 & 34 & 26 & 25 & 0 \\
1904 & 6.5 & 20 & 9 & 21 & 2 \\
1906 & 10.5 & 45 & 3 & 67 & \\
\hline
\end{tabular}

reflects the properties of the parent rock, the conclusions of Muller \& Bocquier (1985) seem to disagree with the results of the present study: the Fe oxides content and hematite content increase upwards, with the goethite content remaining constant throughout the layers extending above the Lower Limonite layer.

The Lower Limonite layer contains considerable amounts of $\mathrm{Ni}$ and $\mathrm{Cr}$, with signficantly smaller amounts of Co (Table 6). The decrease in all three metals in the Lower Breccia is remarkable. Although the metal contents again increase upwards and show a significant positive correlation with the DCB-extracted Fe contents, this distribution is rather chaotic and may suggest different cycles of erosion and pedimentation.

\section{CONCLUSION}

The Fe-bearing mineral identified in the serpentinite protolith is magnetite. The dominant $\mathrm{Fe}$ oxides in the weathered material are goethite and hematite. These minerals, in association with gibbsite and kaolinite, indicate an advanced degree of weathering. The Mössbauer spectra of both $\mathrm{Fe}$ oxides indicate poor crystallinity and/or significant substitution. Mössbauer spectroscopy indicates that the Lower Limonite layer is very rich in goethite, whereas hematite (in the clay fraction) and magnetite are almost absent. The hyperfine field of goethite decreases from the Upper Limonite to the Lower Breccia presumably due to decreasing $\mathrm{Al}$ substitution. Although the $\mathrm{Al}$ and $\mathrm{Si}$ contents are smaller in the Lower Limonite, there was no further decrease in the hyperfine field due to several parameters, among them the presence of Al-for-Fe substitution. The weathered material, starting from the Lower Breccia and moving upwards, appears to be partly allochthonous, as indicated by the presence of muscovite in the fine-earth and clay fractions. The increasing content of poorly crystallized hematite up the profile, the Al-for-Fe substitution in the goethite phase and the variation in particle size indicate that the material evolved under different pedological conditions compared to the deeper layers. The mixed composition of the Upper Breccia and the chaotic distribution of trace elements suggest significant influence of the surrounding mica-schists or ancient mica-schist capping, which may indicate different cycles of erosion and pedimentation.

\section{ACKNOWLEDGMENTS}

This work was partially supported by the Fund for Scientific Research - Flanders.

\section{REFERENCES}

Baert G., Van Ranst E., Vandeberghe R.E. \& De Weirdt J. (1999) Estimation of Al-for-Fe substitution in goethite by selective dissolution and Mössbauer spectroscopy in a weathering sequence on mafic rocks in the Lower Congo. Malaysian Journal of Soil Science, 3, 11-27.

Bessoles R. (1980) La chain Panafricaine au Cameroun, en Centrafrique, au Tchad et au Soudan en Géologie de l'Afrique. La chain Panafricaine: zone mobile 
d'Afrique Centrale (partie Sud et zone mobile Soudanaise). Mémoire Du Bureau de Recherches Géologiques et Minières, 92, 377 pp.

Cornell R.M. \& Schwertmann U. (2003) The Iron Oxides. $2^{\text {nd }}$ edition. Wiley-VCH, Weinheim, Germany, pp. 433-475 pp.

De Grave E. \& Vandenberghe R.E. (1986) ${ }^{57} \mathrm{Fe}$ Mössbauer effect study of well-crystallized goethite $(\alpha-\mathrm{FeOOH})$. Hyperfine Interactions, 28, 643-646.

De Grave E., Chambaere D. \& Bowen L.H. (1983) Nature of the Morin transition in Al-substituted hematite. Journal of Magnetism and Magnetic Materials, 30, 349-354.

De Grave E., Bowen L.H., Amarasiriwardena D.D. \& Vandenberghe R.E. (1988) ${ }^{57} \mathrm{Fe}$ Mössbauer effect study of highly substituted aluminium hematites: determination of the magnetic hyperfine field distributions. Journal of Magnetism and Magnetic Materials, 72, 129-140.

De Grave E., Persoons R.M., Vandenberghe R.E. \& de Bakker P.M.A. (1993) Mössbauer study of the hightemperature phase of Co-substituted magnetites, $\mathrm{Co}_{\mathrm{x}} \mathrm{Fe}_{3-\mathrm{x}} \mathrm{O}_{4}$. I. $\mathrm{x} \leqslant 0.04$. Physical Review B, 47, 5881-5893.

Eswaran H., Stoops G. \& Sys C. (1977) The micromorphology of gibbsite forms in soils. Journal of Soil Science, 28, 136-143.

Herbillon A.J. (1980) Mineralogy of Oxisols and oxic materials. Pp. 109-126 in: Soils with Variable Charge (B.K.G. Theng, editor). New Zealand Society of Soil Science.

Ingamells C.D. (1966) Absorptiometric methods in rapid silicate analysis. Analytica Chemica Acta, 38, 1228-1234.

Lambiv Dzemua G. (2005) Mineralogical and micromorphological characterization of weathered serpentinite from south-east Cameroon. MSc thesis, Inter-university Programme in Physical Land Resources, Ghent University, Belgium, 105 pp.

Mehra D. \& Jackson M. (1960) Iron oxide removal from soils and clays by dithionite-citrate system buffered with sodium bicarbonate. In: Proceedings of the $7^{\text {th }}$ Clay Conference on Clays and Clay Minerals. New York, 317-327.

Milesi J.P., Toteu S.F., Deschamps Y., Feybesse J.L., Lerouge C., Cocherie A., Penaye J., Tchameni R., Moloto-A-Kenguemba G., Kampunzu H.A.B., Nicol N., Duguey E., Leistel J.M., Saint-Martin M., Ralay F., Heinry C., Bouchot V., Mbaigane J.C.D., Kula V.K., Chene F., Monthel J., Boutin P. \& Cailteux J. (2006) An overview of the geology and major ore deposits of central Africa: explanatory note for the 1:4,000,000 map 'Geology and Major Ore Deposits of Central Africa'. Journal of African Earth Sciences, 44, 571-595.

Muller J.P. \& Bocquier G. (1985) Textural and mineralogical relationships between ferruginous nodules and surrounding clayey matrices in a laterite from Cameroon. Pp. 186-194 in: International Clay Conference. Denver, USA, (L.G. Schultz, H. van Olphen \& F.A. Mumpton, editors). The Clay Minerals Society, Bloomington, Indiana, USA.

Murad E. (1998) Clays and clay minerals: what can Mössbauer spectroscopy do to help understand them? Hyperfine Interactions, 117, 39-70.

Murad E. \& Schwertmann U. (1986) Influence of Al substitution and crystal size on the room-temperature Mössbauer spectrum of hematite. Clays and Clay Minerals, 34, 1-6.

Omang S.V. (1969) A rapid fusion method for decomposition and comprehensive analysis of silicates by atomic absorption spectrophotometry. Analytica Chemica Acta, 46, 225-230.

Qafoku N.P., Van Ranst E., Noble A. \& Baert G. (2004) Variable charge soils: their mineralogy, chemistry and management. Advances in Agronomy, 84, 157-213.

Quin T.G., Long G.J., Benson C.G., Mann S. \& Williams J.P. (1988) Influence of silicon and phosphorus on structural and magnetic properties of synthetic goethite and related oxides. Clays and Clay Minerals, 36, 165-175.

Schwertmann U. (1964) The differentiation of iron oxide in soils by a petrochemical extraction with acid ammonium oxalate. Zeitschrift Fuer Pflanzenernaehrung Duengung, Bodenkunde, 105, 194-202.

Schwertmann U. \& Pfab G. (1996) Structural vanadium and chromium in lateritic iron oxides: genetic implications. Geochimica et Cosmochimica Acta, 60, 4279-4283.

Schwertmann U., Friedl J., Stanjek H. \& Schulze D.G. (2000) The effect of clay minerals on the formation of goethite and hematite from ferrihydrite after 16 years' ageing at $25^{\circ} \mathrm{C}$ and $\mathrm{pH} 4-7$. Clay Minerals, 35, 613-623.

Sieffermann G. \& Millot G. (1969) Equatorial and tropical weathering of recent basalts from Cameroon: allophanes, halloysite, metahalloysite, kaolinite and gibbsite. Proceedings of the International Clay Conference, Tokyo, 1, 417-430.

Trolard F., Bourrie G., Jeanroy E., Herbillon A.J. \& Martin H. (1995) Trace metals in natural iron oxides from laterites: a study using selective kinetic extraction. Geochimica et Cosmochimica Acta, 59, 1285- 1297 .

Vandenberghe R.E. \& De Grave E. (1989) Mössbauer effect studies of oxidic spinels. Pp. 59-182 in: Mössbauer Spectroscopy Applied to Inorganic Chemistry (G.J. Long \& F. Grandjean, editors). Plenum Press, New York.

Vandenberghe R.E., De Grave E., De Geyter G. \& Landuydt C. (1986) Characterization of goethite and hematite in a Tunisian soil profile by Mössbauer 
spectroscopy. Clays and Clay Minerals, 34, 275-280.

Vandenberghe R.E., De Grave E., Landuydt C. \& Bowen L.H. (1990) Some aspects concerning the characterization of iron oxides and hydroxides in soils and clays. Hyperfine Interactions, 53, 175-196.

Vandenberghe R.E., Barrero C.A., Da Costa G.M., Van San E. \& De Grave E. (2000) Mössbauer characterization of iron oxides and (oxy)hydroxides: the present state of the art. Hyperfine Interactions, 126, 247-259.

Vandenberghe R.E., De Grave E. \& Da Costa G.M. (2001) About the Morin transition in hematite in relation with particle size and aluminium substitution. Czechoslovak Journal of Physics, 51, 663-675.

Van Ranst E. (1995) Rational soil management in the humid tropics. Mededelingen der Zittingen Koninklijke Academie voor Overzeese Wetenschappen, 40, 209-233.

Van Ranst E. \& Eswaran H. (1998) Managing red and lateritic soils of the humid tropics as related to their mineralogical and charge properties. Pp. 279-291 in: Red \& Lateritic Soils. Vol. 1. Managing Red and Lateritic Soils for Sustainable Agriculture (J. Sehgal, W.E. Blum \& K.S. Gajbhiye, editors). Oxford \& IBH Publishing, New Delhi.

Van Ranst E., Shamshuddin J., Baert G. \& Dzwowa P.K. (1998) Charge characteristics in relation to free iron and organic matter of soils from Bambouto Mountains, Western Cameroon. European Journal of Soil Science, 49, 243-252.

Van Wambeke A., Eswaran H., Herbillon A.J. \& Commerma J. (1980) Oxisols. Pp. 325-350 in: Pedogenesis and Soil Taxonomy, Part II (L.P. Wilding, N.E. Smeck \& G.F. Hall, editors). Elsevier, Amsterdam.

Yerima B.P.K. \& Van Ranst E. (2005) Major Soil Classification Systems Used in the Tropics: Soils of Cameroon. Trafford Publishing, Canada, 295 pp.

Yongue-Fouateu R., Ghogomu R.T., Penaye J., Ekodeck G.E., Stendal H. \& Colin F. (2006) Nickel and cobalt distribution in the laterites of the Lomie region, south-east Cameroon. Journal of African Earth Sciences, 45, 33-47. 